\title{
Architecture, Ecology and Economy: Synergy or Contradiction?
}

\author{
Marcus Hackel ${ }^{1, *}$ and Anne Hackel $^{2}$ \\ ${ }^{1}$ Prof. Dr.-Ing. Architect, Hochschule Wismar, University of Applied Sciences: Technology, Business \\ and Design, Faculty of Architecture and Design, Germany \\ ${ }^{2}$ Dipl.-Ing. , Beuth University of Applied Sciences, Berlin, Germany
}

\begin{abstract}
Economy and ecology in architecture are seen by most as contradictions. On the other hand traditional building concepts and vernacular architecture all over the world use local renewable materials and building methods as well as designs based on optimizations, traditions and culture and thus follow an economic and ecologic approach. The environment is not a world outside the economy. Well considered ecologic approaches and solutions for socio-ecological problems can trigger innovation and economic success. As architects we have an increasing responsibility towards sustainability. In this context the use of building cost optimization and life cycle cost optimization without compromising quality will be part of the „Ecological Economy in Architecture”. The goal will be to create consumer value on several levels. Ecologic architectural projects will create economic competitive advantage in conjunction with the creation of unique selling points. The starting points will be the wellbalanced analysis and management of economic efficiency, ecological, social and cultural aspects - considering all stakeholders and the whole lifecycle of buildings. Hence current ways of design, decision-making, communication and education must be questioned from all sides.
\end{abstract}

Key Words: ecological economy in architecture, environmental economics, economic ecology, architectural sustainability, sustainability marketing, $4 \mathrm{Cs}$, life cycle cost optimization, unique selling point, competitive advantage, consumer value, push and pull, green marketing myopia.

\section{Problem}

Growth is the overall goal of nowadays economy and politics and the driving force of real estate developments. Today numerous regions of the world experience a growth in economy combined with a booming building sector. Growth creates additional value within the real estate field but at the same time it must be seen alongside with its possible negative consequences in the matters of ecology, social life and culture. This in turn leads to an increasing responsibility of architects towards sustainability.

\footnotetext{
* Corresponding author: marcus.hackel@hs-wismar.de
} 
The "Limits of Growth" have been discussed since at least the fundamental and very influential book of Meadows e.a. in 1972 (1). Ecologic urban design and architectural projects started conceptual and humble and only have been built in urban scale since the late $1990^{\text {th }}$ in projects like Vauban, Freiburg (2) and Flintenbreite Luebeck (3). In the $2000^{\text {th }}$ large scale developments like Masdar, AbuDhabi (4) or JingYue Ecological City, Changchun (5) have been a new focus of architectural and urban design discussions. But these large scale projects proofed to be difficult. The financing and realisation process is complex, and the measurement of success is controversial. What should be included in the carbon dioxide evaluations is if employees commute in large SUVs. What are the models to calculate the overall ecological footprint and to analyse the whole life cycle? The Masdar urban development has been delayed and only been built in parts so far. And neighbouring large scale developments like Saadiyat Island in Abu Dhabi or Marina City in Dubai that do not focus on sustainability have been faster and by far larger in volume.

Nevertheless green and sustainable goods and services worldwide got growing market shares in the last 20 years. Even people who don't believe in climate change are aware of the economic potential of ecology. This on the one hand helps to foster sustainable development, but on the other hand risks come alongside the economic potential of green approaches. With the growing economic success of ecologic goods and services we can see more developments that aim to mislead the customers, hurt competing sustainable approaches and in the end might even harm the environment like greenwashed products and projects "when a company or organization spends more time and money claiming to be "green" through advertising and marketing than actually implementing business practices that minimize environmental impact”. (6).

\section{Green Marketing Myopia}

Marketing Myopia is a term coined by Theodore Levitt in 1960 (7). It is a "short-sighted and inward looking approach to marketing that focuses on the needs of the company instead of defining the company and its products in terms of the customers' needs and wants. It results in the failure to see and adjust to the rapid changes in their markets." (8)

Designers and architects who pursue ecologic concepts have to be aware of the "Green Marketing Myopia". We can currently see two versions of the "Green Marketing Myopia" in architecture.

Some architects, engineers and customers perceive ecology as the main philosophy, lifestyle and focus of their activities. The overemphasis of just one characteristic of architecture, even so it is very important, may easily lead to wrong developments. Other important design elements like functionality, aesthetics, cost-benefit-balance and other stakeholder needs might be neglected and will lead to an overall long term failure. Aesthetically unpleasant buildings, covered with thick layers of insulation and only optimized surface-to-volume ratio in which tenants are not allowed to open their windows to optimize energy consumption in Germany will not be successful in the long run.

The second version of the "Green Marketing Myopia" in architecture is the overall focus on green solutions through technology. Customers very often prefer high tech to low tech solutions. They are visible, tangible, and innovative and can easily be sold. They help to communicate green architecture because for example intelligent double layered facades like Sauerbruch Hutton`s GSW Headquarter in Berlin, visible solar cells or wind turbines like Atkins` Bahrain World Trade Center in Manama answer the question "how does sustainable architecture look like". Similar to other high tech approaches it is important to evaluate the overall ecological footprint and to analyse the whole life cycle of e.g. wind turbines that have no recycling or upcycling concept yet. Costs and the ecologic foot print 
of the maintenance for the whole life cycle have to be included into the sustainability evaluation. This second version of "Green Marketing Myopia" in architecture again has the risk of focussing only on one way of sustainable solutions and neglecting other consumer needs. We can learn from traditional and vernacular architecture and its intelligent low-tech low-cost approaches. These traditional architectural designs where based on bioclimatic principles and cultural values "Less is more" is a phrase used by Ludwig Mies van der Rohe to describe his straight forward minimalistic design approaches. We could also use "less is more" as a concept for sustainable architecture to question the technology based focus.

I define "Green Marketing Myopia" for architects as the short-sighted focus above all on the green optimized qualities of their projects. Being convinced of the needs of our planet and future generations for a sustainable approach we easily forget that products comprise a large bundle of qualities. We have to keep in mind that we should focus on the diverse expectations of our clients, stakeholders and the society in large. Customers decide about architecture among others because of their functional qualities, aesthetics and design qualities, image and recognition, health, joy, well feeling and economic optimization. To be successful in the markets of the future we will have to keep all decision making factors in mind and we will have to shift the discussion from ecology versus economy to an "Ecologic Economy" or an "Economic Ecology" approach.

\section{3 "Ecological Economics in Architecture"}

Talking about architectural qualities we normally cite the three principles of Vitruvius "De Architectura"(9):

Durability (Firmitas), Utility (Utilitas) and Beauty (Venustas). Among these three keywords neither economy nor ecology are to be found. But Virtuvius also mentions „Distributio“, the appropriate use of sites, materials and respecting local conditions. This allocation of resources should be inexpensive and economic. As mentioned in paragraph 2 traditional and vernacular architecture follow this philosophy. In traditional dwellings like e.g. the Bavarian farmers house in southern Germany for cold temperate climate, the architecture of the Ksour in northern Africa responding to the dry hot climate of the desert or the Batak architecture in Sumatra, Indonesia ideal for wet tropical climate the bioclimatic design and the choice of local renewable materials and building methods as well as designs based on optimizations, traditions and culture follow an economic and ecologic approach.

The Encyclopaedia Britannica defines Environmental Economics as an interdisciplinary approach with a focus on the allocation of natural resources:

"Environmental economics, subdiscipline of economics that applies the values and tools of mainstream macroeconomics and microeconomics to allocate environmental resources more efficiently.

On the political stage, environmental issues are usually placed at odds with economic issues; environmental goods, such as clean air and clean water, are commonly viewed as priceless and not subject to economic consideration. There is, however, substantial overlap between economics and the environment. In its purest form, economics is the study of human choice. Because of that, economics sheds light on the choices that individual consumers and producers make with respect to numerous goods, services, and activities, including those made with respect to environmental quality. Economics can not only identify the reasons why individuals choose to degrade the environment beyond what is most beneficial to society, but it can also assist policy makers in providing an efficient level of environmental quality. Environmental economics is interdisciplinary in nature, and, 
thus, its scope is far-reaching. The field, however, remains rooted in sound economic principles."(10)

For the further discussion about "Ecological Economy in Architecture" the insight is important that environmental issues are usually seen in contrast with economic issues. This not only applies to politics but also to many investors in real estate. It is also important to realise that in its purest form, economics is the study of human choice and that these choices are made with respect to many perspectives including environmental quality. The important insight is that environmental goods, such as clean air and clean water, are commonly viewed as priceless and not subject to economic consideration. The macroeconomic effects nevertheless have to be taken into account even so they are complex to calculate. They are difficult to communicate to investors who normally do not care about the use of resources as long as they are readily available and free of charge. These macroeconomic implications on the "Ecological Economy" are an additional topic that needs further research for its effects on architectural design but will not be discussed further in this paper.

Van den Berg defines the main aspect of Ecological Economics "The core of EE can be associated with the goal of sustainable development, interpreted as both intra- and intergenerational equity; the view that the economy is a subsystem of a larger local and global ecosystem which sets limits to the physical growth of the economy."(11) Van den Berg in contrast to the Encyclopaedia Britannica defines economy as a subsystem of the ecosystem. Including the limits of physical growth this definition reflects the current and visible problems of unbalanced development, untamed city growth, pollution, limits of resources and problems of material cycles. It demands a general mind shift and is more fundamental. Following this definition architects will collide with the current approaches of economists that see grows as a base and measurement for success. With this line of reasoning architects will face problems to voice the arguments for their design. One solution to develop a common ground with investors will be to estimate the long term costs of building, use and disposal and include this into the initial forecast for the overall return of investment. This concept will only work for an extended period of use and not for booming markets with an extreme ROI and an economic life cycle of less than 20 years. Complex architectural design concepts that take into account the whole life cycle will need a more interdisciplinary design process and the input of specialised engineers, e.g. facility managers, biologists and social scientists.

To bring together ecology and economy Peattie and Belz emphasise four areas that will need different and innovative thinking in sustainability marketing:

- "treating socio-ecological problems as a starting point of the marketing process, not as a set of externalities or constraints;

- understanding consumer behaviour holistically;

- reconfiguring the marketing mix;

- appreciating and utilising the transformational potential of marketing activities and relationships." (12)

We have to keep in mind that socio- ecological problems are not an economic obstacle. Instead they can be the starting point for product innovation and economic success. To really understand the customer needs we have to shift our mind, follow a more holistic approach and ad new concepts to the marketing mix. Instead of focussing only on 
McCarthy`s traditional 4 Ps (Price, Product, Promotion and Place) we should consider Belz and Peattie`s $4 \mathrm{Cs}$ for the more customer oriented sustainability marketing mix:

-Customer solutions

- Customer cost

-Convenience

-Communication (12)

Applying the above insights on architecture we can now find solutions to dissolve the contradiction of ecology and economy. But how can we activate the „Ecological Economy in Architecture" today?

We can base our approach on the insight of Jacquelyn Ottman "The real news in today's green marketplace is that thanks to new technology, many green products have greatly improved-- some to the point of true superiority over their conventional counterparts. Many can now attract users on the basis of cost, health and convenience-benefits that appeal to all consumers, and the reasons why consumers buy certain products in the first place.(...) We as Americans need to be aware that some of the most compelling innovations these days are coming from Europe and Japan, where ecologically conscious consumers, as well as government regulations and incentives like extended producer responsibility, have pushed companies to progress to the next generation of environmentally sound, high performance products."(13)

The insight for architects in this article is that innovation and competitiveness can be driven by an ecological approach. Government intervention as regulations and incentives (push and pull) can facilitate this process. Peattie and Belz even see the long term effects and transformational potential of marketing activities and relationships in politics and culture and society. (12)

To achieve „Ecological Economy in Architecture” several parallel concepts will have to be employed:

- Building cost optimization through ecologic approaches including e.g. inexpensive renewable natural materials, recycling, upcycling or regaining.

This can also be based on intelligent passive bioclimatic ecologic concepts that learn from low-tech and low-cost traditional design.

- Life cycle cost optimization e.g. through long lasting quality or adaptive reuse

Design concepts have to evaluate all cost of maintenance, renewal and disposal and its effects on sustainability.

- Creating of a unique selling point and competitive advantage through sustainability

This unique selling point can be tangible like visible PV, or smart innovative technology or a LEED or DGNB certificate. It can be invisible like well feeling, image or recognition.

- Customer orientation creating ,Consumer Value“"

Customers neither only focus on economic optimization nor only on ecology. They evaluate a large bundle of qualities in architecture like functional, aesthetics and design qualities, image and recognition, health, joy, well feeling and economic optimization 


\section{- Creating ,Brand Value“}

Brand value can be created for the project and the architect. It will show the special position in the market and differentiation from others. It should include a long lasting core value and reputation and could be based on Ecological Economy.

\section{- Use of „Push and Pull“}

These factors include legal pressure for better ecological performance for example through specific legislation as well as benefits like grant programs by the government. In the long run the goal should be a transformation process that changes the public opinion and political activities and institutions towards sustainability (14)

\section{- Avoid to overemphasise green qualities while neglecting customer benefits}

Green Marketing Myopia is a risk for all architects who understand the need for sustainable solutions. Although sustainable urban and architectural developments are much needed, the short-sighted focus above all on the green optimized qualities of projects might stand in the way of long term success.

\section{Conclusion}

Architecture has to provide customer value, high quality combined with a well-engineered approach. This well engineered approach can also be based on intelligent passive bioclimatic ecologic concepts (low-tech and low-cost). It has to bring together the world of economic goals with the value creating world of ecology. Sustainable design approaches in architecture can create unique selling points and competitive advantage triggering innovation. Sustainable buildings are seen as long term investments that demand highest quality in design and built result. The long term effects of urban design and architecture are recognized by most people as an important factor for the economic, ecologic, social and cultural well-being of the society. In this context the use of building cost optimization and life cycle cost optimization without compromising quality in conjunction with the creation of unique selling points finally creating real consumer value will lead to an economic competitive advantage of sustainable architectural concepts. „Ecological Economy in Architecture" has the potential to create consumer and brand value.

The starting points will be the well-balanced analysis and management of economic efficiency, ecological, social and cultural aspects - considering all stakeholders and the whole lifecycle of buildings. Successful sustainable architecture needs architectural design abilities, technological knowledge, economic knowledge and communication - an interdisciplinary approach. Hence current ways of design, decision-making, communication and architectural education must be questioned from all sides.

\section{References}

1. Meadows, Donella e.a. (1972), The Limits of Growths, New York, Universe Books

2. Green City Freibung, Quartier Vauban, www.freiburg.de/pb/site/Freiburg/get/params_E1868593550/647919/Infotafeln_Vauban_en.pdf

3. Oldenburg, Martin, Die ökologische Wohnsiedlung Flintenbreite, Lübeck Fachtagung „Ökologische Siedlungsentwicklung im Spiegel aktueller Trends und Praxiserfahrungen" Osnabrück 
https://oekosiedlungen.de/downloads/dokumente/tagung-siedlungsentwicklung2005/dokumente/Oldenburg.pdf

4. Masdar, Pioneering the Future of Sustainability

https://masdar.ae/

5. Speer, Albert, Changchun, JingYue Ecological City, www.as-p.com/projects/project/changchun-jingyue-oekologische-wohn-undgeschaefts-61/show/

6. EnviroMedia Social Marketing \& the University of Oregon, Greenwashing Index, http://www.greenwashingindex.com/about-greenwashing/

7. Levitt, Theodore, (1960), Marketing Myopia, Harvard Business Review

8 Business Dictionary, Marketing Myopia, http://www.businessdictionary.com/definition/marketing-myopia.html

9. Vitruvius (1914) The Ten Books on Architecture, Oxford University Press

10. Brown, Jennifer, Environmental Economics, Encyclopaedia Britannica, www.britannica.com/topic/environmental-economics

11. Van den Berg, Jeroen; Ecological economics: themes, approaches, and differences with environmental economics www.ima.kth.se/utb/mj2694/pdf/Bergh.pdf

12. Peattie, Ken, Belz, Frank-Martin, Sustainability Marketing: An Innovative Conception of Marketing

www.researchgate.net/profile/Frank-Martin_Belz/ publication/225723866_Sustainability_marketing__An_innovative_conception_of_marketing/links/0-0eec52791fff5a882000000/Sustain ability-marketing-An-innovative-conception-of-marketing.pdf

13. Ottman, Jacquelyn, The Real News About Green Consuming, The Green Business Letter, May 2002, www.greenmarketing.com/index.php/articles/complete/the-real-news-about-greenconsuming/

14. Belz, Frank-Martin, Karstens, Birte, Strategic and Instrumental Sustainability Marketing in the Western European Food Processing Industry http://www.crrconference.org/Previous_conferences/downloads/belz.pdf 